\title{
Corporate Ownership Structure as a Determinant of "Risk Taking": Insights from Italian Listed Companies
}

\author{
Pier Luigi Marchini ${ }^{1}$, Veronica Tibiletti ${ }^{1}$, Alice Medioli ${ }^{1}$ \& Gianluca Gabrielli ${ }^{1}$ \\ ${ }^{1}$ Dipartimento di Scienze Economiche e Aziendali, Università degli Studi di Parma, Parma, Italy \\ Correspondence: Pier Luigi Marchini, Dipartimento di Scienze Economiche e Aziendali, Università degli Studi di \\ Parma, Parma, Via J.F. Kennedy n.6, Italy. E-mail: pierluigi.marchini@unipr.it
}

Received: August 4, 2020

Accepted: September 10, 2020

Online Published: October 21, 2020

doi:10.5539/ijbm.v15n11p138

URL: https://doi.org/10.5539/ijbm.v15n11p138

\begin{abstract}
Ever since major accounting scandals and corporate collapses of the early 2000's, the improved risk taking and the lax approach to risk management procedures, which are viewed as contributing factors to the market breakdown that occurred in the international market and, in particular, in the U.S. in 2007, have led to an increased awareness of the importance of managing risk on the part of listed companies. Risk management has gained importance in the definition of what it means to be the best and most efficient corporate governance structure and mechanism, as it can play a fundamental role in helping to achieve the company's target. Also disclosure related to risk management is fundamental for the efficient functioning of capital markets since it helps to improve corporate transparency and to reduce the information asymmetry between insiders and outsiders.

This paper aims to investigate the relationship between ownership structure and corporate risk-taking behavior and disclosure, as a tool for protecting shareholders, among Italian listed companies. The analysis is devoted to the Italian stock market because it is strongly characterized by a high ownership concentration and by the presence of a family ownership model; and this scenario makes the Italian one an interesting case to study. Based on a sample of 233 Italian listed companies, through a multivariate regression, we find that a high level of ownership concentration is positively related to a firms' low level of risk taking by the board of directors, so giving interesting insights to regulators and practitioners, as well as for further research.
\end{abstract}

Keywords: risk taking, disclosure of risks, ownership structure, corporate governance

\section{Introduction}

Companies, regardless of their business sector, carry out their activities in a very complex socio-economic environment, where it is essential to perform functions related to risk monitoring (Caldarelli et al., 2016). Organizations operate in increasingly dynamic, complex, and unpredictable contexts (McMullen \& Shepherd, 2006), and thus, exploring and managing related risks is a prerequisite (Alchian, 1950). Risk management has considerable implications for competitiveness and business; it enables, for instance, the development of a potential loss reduction strategy while taking advantage of windows of opportunity (Radner \& Shepp, 1996).

Business activity is, by definition, characterized by the existence of risk that cannot be completely eliminated but that may, at least, be managed in a way that minimizes them. Therefore, risk management practices are crucial as an effective risk management is not about eliminating risk taking, which is indeed a fundamental driving force in business and entrepreneurship (OECD, 2014).

In the past, risk management played a marginal role in a company's strategy selection, since distinct and separate measures were taken singularly to contain the uncertainty arising from specific activities. However, the combination of risks to which companies are exposed is as complex as the enterprise system itself, and it requires both a professional and profound approach (OECD, 2014).

The last twenty years have been marked by a "wave" of corporate scandals in addition to a major global crisis. In the wake of the major accounting scandals and corporate collapses of the early 2000's (Power, 2004), the global financial crisis of 2008 (Lehuede et al., 2012), the European sovereign debt crisis from 2009 to 2012 (De Marco, 2019), as well as the recent cybercrime impact on business (Crovini et al., 2018), risk management practices and risk disclosure have, thus, attracted increased attention. 
The global financial crisis, in particular, captured the attention of not only researchers and practitioners but also of international standard setters who have recognized the need for establishing comprehensive risk awareness for companies (IIF, 2009; Lam, 2014; Melnyk et al., 2014). In this climate, new corporate governance codes and rules have been produced by the regulators with the aim of establishing better and more effective control mechanisms. These new codes reflect the perspective that risk management and corporate governance principles should be integrated given that risk management is a formidable element of corporate governance practices (McCrae \& Balthazor, 2000; Margaret Woods, 2009).

Corporate governance includes a system of rules regarding ownership structure and companies' boards of directors, and, therefore, it is a decisive factor for economic growth and for the level of investor confidence (OECD, 2004), as well as for the development of financial markets (La Porta et al., 2002). Risk taking is an essential ingredient in today's business world due to the fact that a company must, in its decision-making process, make choices that lead to rational and informed decisions about the risks it wishes to undertake in pursuit of the objectives that the organization has set for itself. In fact, in order to be able to align their strategy and risk management with the goal of gaining a competitive advantage, they must be able to define their appetite and tolerance for risk and to set target levels for presumed risks. In other words, a company needs to understand how much risk it is willing to take and, above all, how it intends to balance risks and opportunities before designing and executing any given strategy (Deloitte, 2012).

Many studies show that entrepreneurs' willingness to take risks in the pursuit of profitable opportunities is a fundamental underpinning of long-term economic growth (Acemoglu \& Zilibotti, 1997; Baumol et al., 2007; De Long \& Summers, 1991; John et al., 2008). Value is a function of risk and return (Deloitte, 2012), and every decision either increases, preserves, or erodes value. Given that risk is integral to the pursuit of value, strategic-minded enterprises do not strive to eliminate risk or even to minimize it; this perspective represents a critical sea change from the traditional view of risk as something to avoid. Rather, these enterprises seek to manage risk exposure across all parts of their organizations so that, at any given time, they incur just enough of the right kinds of risk - no more, no less - to effectively pursue strategic goals (Deloitte, 2012).

Much of the previous studies on corporate governance and ownership structure examine the problem of separation between ownership and management (Fama \& Jensen, 1983; Jensen \& Meckling, 1976). The relationship between the board of directors, risk taking, and firm performance has been widely explored. On the contrary, the relationship between risk taking and the ownership structure of the company appears to have been less thoroughly investigated.

Furthermore, the existence of a global financial crisis is evidence of not only a lack of good, widely adopted risk management policies, but also of a problem concerning risk information and disclosure. Firms' risk management disclosure has also received increasing attention in the international community and in financial markets. As the risk appetite gets defined by management, it becomes their responsibility to communicate risk levels throughout the organization to ensure that the actions the company takes at all levels are in line with the risk the company is willing to accept. Several studies have investigated the determinants of risk disclosure and found that it can be explained by specific firm characteristics (Elshandidy \& Neri, 2015; Linsley \& Shrives, 2006; Zhang et al., 2013) and corporate governance structure (Abraham \& Cox, 2007; Elshandidy \& Neri, 2015; Oliveira et al., 2011; Said Mokhtar \& Mellett, 2013); other studies have examined risk disclosure quality and its determinants (Abraham \& Shrives, 2014; Beretta \& Bozzolan, 2004; Martikainen et al., 2015; Miihkinen, 2012).

In accordance with the increasing importance given to risk taking policies and to the disclosure of the risks policies adopted, the aim of this study is to understand how ownership structure influences companies' comprehensive attention to risk and the consequent disclosure as defined by the board of directors, as a tool for protecting shareholders.

Using all public information and public documents on the company's website, we study 10 different issues that we consider to be indicators of high-risk awareness by the firm and, by means of a multivariate regression, we test whether a high level of ownership concentration is positively related to firms' low risk taking by the board of directors, intended as risk management policies and disclosure adopted.

Our results are consistent with the study of Dyck \& Zingales, 2004, Fama \& Jensen, 1983 and Shleifer \& Vishny, 1997 supporting the idea that concentrate ownership may create agency conflicts (Dyck \& Zingales, 2004; Fama \& Jensen, 1983; Shleifer \& Vishny, 1997) and that controlling shareholders can easily extract private benefits of control at the expense of minority investors (Moscariello et al., 2019; Nenova, 2003; Zingales, 1994). Our study supports the idea that concentration is closely related to more risk taking (Amihud \& Lev, 1981; Anderson \& Reeb, 2003), reducing risk awareness (Brammer \& Pavelin, 2006; Eng \& Mak, 2003). 
This study has theoretical and practical implications.

First of all, our findings fill a gap in the field of study that analyses the relationship between corporate governance characteristics and the risk taking policies of the companies, as we analyzed an area that has not been studied widely in the literature, that is how shareholders' conception of a company is dependent on the disclosure of risk policies of a company.

Taking into consideration all the varied practical implications, this study provides insights for regulators to enhance the adoption of policies aimed at managing and communicating corporate risks, while introducing more restrictive policies for companies with concentrated ownership that are less proactive and fair in the implementation of comprehensive risk management practices and disclosure.

The research should help practitioners by empowering them to support companies with regards to the development of risk management systems and the promotion of new and more complete forms of risk disclosure for those less pro-active companies with regards to risk taking practices.

Lastly, this research is designed to help companies that are less focused on the development of risk management policies to comply with the best standards in order to be less vulnerable when adverse events occur.

The remainder of this paper is organized as follows: after the Introduction, Section 2 presents a summary of prior studies and develops hypotheses; Section 3 describes the methodology used in the study; and Section 4 presents the main results and a discussion; and Section 5 concludes.

\section{Literature Review}

\subsection{Agency Theory and Corporate Governance}

Corporate governance involves a set of relationships between a company's management, its board, its shareholders, and other stakeholders. Corporate governance provides the structure through which the objectives of the company are set and determines the means of attaining those objectives and monitoring performance (OECD, 2014). Corporate Governance is further defined as the relationship between the various players in determining the general direction and performance of the company; the primary stakeholders are shareholders, while management is led by the managing director and the board of directors (Monks \& Minow, 2001).

The rise of a challenging economic climate has led to the preponderance of new needs to be met and to the development of new governance structures, in which managers with specific skill sets ensure a better decision making process. This has led owners to delegate the control of their companies, thus establishing an agency relationship that occurs when one or more subjects proxy the performance of certain activities to others. Agency theory states that conflicts of interest may arise between owners and managers due to a divergence of objectives and information asymmetry resulting from the separation of ownership and control (Fama, 1980; Jensen \& Meckling, 1976). The owners aim to maximize the value of the company with a long-term perspective, while managers may implement opportunistic behavior in order to maximize their utility function in the short term to improve their reputation and competitiveness. Therefore, agency theory allows us to explicitly incorporate conflicts of interest, incentive problems, and mechanisms for controlling incentive problems into our models (Lambert, 2001).

In an agency setting that features ownership concentrated into the hands of dominant shareholders, the presence of shareholders in the board as either (mostly) executive and non-executive directors can be expected (Shleifer \& Vishny, 1997). Insider shareholders exercise direct supervision on management or they are managers themselves, leading often to a board that serves as Presidents and/or CEOs. This, in turn, serves to align the interests of ownership and management. Nevertheless, other agency conflicts arise in such a scenario.

Agency conflicts occur between different types of shareholders when the ownership structure is characterized by the presence of a strong majority of shareholders. Dominant shareholders could represent and pursue their own interests, which may not coincide with those of minority investors. Therefore, they could try to maximize their own profit and expropriate wealth from other stakeholders, such as the employees or smaller investors (Dyck \& Zingales, 2004; Fama \& Jensen, 1983; Shleifer \& Vishny, 1997).

Many prior studies document the existence of this kind of agency problem (Anderson \& Reeb, 2003; Claessens et al., 1999; DeAngelo \& DeAngelo, 2000; Faccio et al., 2001). DeAngelo and DeAngelo (2000) find that big shareholders in public firms extracted private rents through extraordinary dividends, excessive compensations schemes, and related-party transactions. Faccio et al. (2001), after studying the dividend policy of companies, find empirical evidence of wealth expropriation by controlling shareholders.

In order to realign the two divergent targets of managers and owners, the literature proposes using internal 
control mechanisms, such as the board of directors, incentives to managers, and debt, as well as external governance systems, such as the market for corporate control and product market competition (Fama, 1980). The Board of Directors plays a determining role in corporate governance mechanisms by monitoring the managers' opportunistic behavior (Fama \& Jensen, 1983). The literature is full of debates about what constitutes more efficient ownership structure and the role of the Board of Directors as a mechanism for control and monitoring, starting with the work of Fama (1980) and Fama and Jensen (1983), according to which managers may adopt risk-averse investment decisions and then choose less risky projects that would penalize the competitive advantage and the survival of the enterprise. Agency theory also highlights that the availability of information is essential for reducing the information asymmetry between the parties involved; therefore, a good risk disclosure could help in performing good corporate governance practices and ensure the efficiency of capital markets.

\subsection{Corporate Governance and Risk Taking}

The relationship between corporate governance and risk taking can be investigated from two different perspectives: linking risk taking with ownership structure or linking risk taking with the board of directors, along with its internal committees (Rossi, 2016). The board has often been analyzed in relation to the firm's performance in terms of size (Yermack, 1996) and composition (R. B. Adams \& Ferreira, 2009; Agrawal \& Knoeber, 1996). The same approach has been used to study the relationship between boards of directors and risk taking.

With regards to the size of the board and risk taking, many Authors favor a smaller board because it assures more efficiency in monitoring and more cohesion in the decision-making process that enable them to avoid extreme decisions (Jensen, 1993; Lipton \& Lorsch, 1992). Some studies find a negative relationship between risk taking and board size (R. Adams \& Ferreira, 2010; S. Cheng, 2008; Nakano \& Nguyen, 2012; Wang, 2012). Regarding the composition of boards, agency theory suggests that the presence of a greater number of independent directors improves performance and monitoring action (Fama \& Jensen, 1983; Jensen \& Meckling, 1976). In relation to the risk, the literature shows a negative and significant relationship between the presence of independent directors and risk taking (Brick \& Chidambaran, 2008; Pathan, 2009). These studies show some consistent results with other contributions, which have all found a negative but, in these cases insignificant, relationship between risk taking and independence of the board (Lewellyn \& Muller-Kahle, 2012; Mathew, 2013). A board's composition and risk can also be studied with regards to gender diversity. Women are considered to be more risk averse than men (Barber \& Odean, 2001; Charness \& Gneezy, 2012). Faccio et al. (2016) examine a large sample of firms, and firms with women as CEOs show lower levels of leverage, lower earnings volatility, and a greater likelihood of survival. Similar results come from Levi et al. (2014) and Sila et al. (2016). The decisions of the board of directors should, therefore, include and consider the nature and extent of the risks to the company, as well as the extent and categories of risk that it considers acceptable to the company.

While there is an extensive body of literature on the relation between board of directors and risk taking, there are fewer contributions about the influence of ownership structure on this topic. Some Authors focused on the role of large and major shareholders on corporate risk taking and policies (Amihud \& Lev, 1981; Boubaker et al., 2016; Faccio et al., 2011; John et al., 2008; Paligorova, 2010), others focus on risk policies of family businesses, which typically have concentrated ownership (Anderson \& Reeb, 2003). Other contributions showed that firms with less-concentrated ownership invest in higher-risk projects, such as R\&D and skill-intensive activities (Carlin \& Mayer, 2003; John et al., 2008; Laeven \& Levine, 2008; Wright et al., 1996)

\subsection{Corporate Governance, Risk Taking and Corporate Risk Disclosure}

There is an expanding amount of literature in which academics seek to identify the power and effectiveness of disclosure in creating better governance environments for policies. According to Stiglitz and Weiss (1981), a stronger information flow can improve resource allocations through the mitigation of principal-agent problems. Kanodia and Lee (1998) and, similarly, Healy and Palepu (2001), point that company disclosure helps in the monitoring of managers' actions to prevent the expropriation of investor health. Regarding the ownership structures, Mitton (2002) argues that better corporate disclosure affected stock performance during the East Asian financial crisis of 1997-1998 by preventing the expropriation of the wealth of minority shareholders.

Corporate disclosure has the ability to provide relevant benefits with its governance role, but the channels through which value is created are not yet well understood. It is possible that an increased or improved level of reporting does not affect economic performance strictly by, for example, reducing agency costs. The benefits of an expanded disclosure activity for the company are also attributable to a lower adverse selection and estimation risk.

While there is a significant amount of academic and professional work on risk management practices and risk 
taking, there is still a small body of research on corporate risk disclosure (Woods et al., 2007). Risk disclosure should improve a corporation's transparency and reduce the information asymmetry between insiders and outsiders, as illustrated by the agency theory, by providing users of financial reports with information on the risk to which a firm is exposed, and on how these risks are managed (Dobler, 2008; Jorgensen \& Kirschenheiter, 2003; Linsley \& Shrives, 2006). Risk disclosure covers a broad set of information on risk sources and on the means of risk management that can vary in location, scope, and nature. Information may be provided through financial statements or different public sources.

Studying risk disclosure is important because corporate transparency about risk is vital for the efficient functioning of capital markets. To achieve and maintain an accurate evaluation of a company's stock, confident and well-informed investors are necessary (Deumes, 2008). As far as the lack of an adequate disclosure is concerned, managers have more information then outside investors, who may not fully understand the underlying risks and rewards of a firm's business (Hutton, 2004). According to Fuller \& Jensen (2002), being transparent about risks and uncertainties can prevent severe damage to the reputation and long-term health of a company that may otherwise result from overvalued corporate equity.

Prior literature includes many investigations into the determinants of corporate risk disclosures, and findings showed that some firm-level characteristics, including firm size, cross listing, firm risk, and board characteristics, may influence risk disclosure (Abraham \& Cox, 2007; Dobler et al., 2011; Jia et al., 2016). For example, Jia et al. (2016) found that firm size and cross listing affected the amount of risk communication in Australia. (Miihkinen, 2012) examine the risk management disclosure of listed Finnish firms, finding that firm risk, leverage, firm size, and cross listing are associated with risk disclosure quality. Elshandidy \& Neri (2015) show that corporate governance variables, including board size and the percentage of non-executive directors, are important determinants of voluntary and mandatory risk disclosure. A determining role for the definition of a corporation's risk management policies is played by the risk management committee, so it is reasonable to argue that the committee is associated with corporate risk disclosure. However, few studies have provided insights into this area.

Disclosure is a determinant part of the comprehensive approach of a company to risk management and can play a fundamental role in reducing the asymmetry between owners and directors identified in agency theory.

It is the governance structure itself that encourages managers to adopt the best disclosure policy (Core, 2001; Karamanou \& Vafeas, 2005). Furthermore, Sloan (2001) argues that corporate disclosure is one of the corporate governance mechanisms employed for the purposes of external management oversight. These studies have shown, consistent with their theoretical propositions, a relationship between corporate governance and voluntary disclosure based on the latter's role as a control mechanism for agency problems. The effects of corporate governance on reporting practices mitigate information asymmetry and improve the stewardship function. Accurate risk information, such as an external control mechanism that reduces agency costs, is fundamental for shareholders, analysts, and investors, as it enables them to assess a company's risk profile, estimate its market value, and make accurate investment decisions (Campbell et al., 2014; Jorion, 2002; Kravet \& Muslu, 2013; Miihkinen, 2013; Rajgopal, 1999).

There are few contributions to the literature that have studied the impact of ownership structure on the level of risk disclosure, which is another worthy topic that correlates a comprehensive approach to risk taking and the management of firms. The level of risk that a firm is willing to accept can be affected by the ownership structure and can help in understanding a part of the complete corporate risk management and approach. In addition to risk taking, risk disclosure represents an instrument that allows us to understand the degree of protection for shareholders who can face the risk of an expropriation of wealth from shareholders who control the company.

\subsection{Ownership Concentration}

Regarding ownership, some studies have empirically examined the relationship between ownership structure and risk taking with mixed results. A finding that has arisen from these studies is that companies from countries with better investor protection have higher firm-specific risk and higher performance (Ferreira \& Laux, 2007; Morck et al., 2000).

It is important to underline the relevance of the recent debate over the impact of the ownership structures on the success of a company's ascension, especially with regards to whether the separation of ownership and control facilitates firm growth (Fama \& Jensen, 1983). More specifically, the controversy is whether family firms, whose ownership and control are concentrated, have better firm performance (Jiang \& Peng, 2011a; Peng \& Jiang, 2010). Empirical studies have led to mixed results, and institutional and social contexts have been identified as contributing to these results (Aguilera \& Jackson, 2003; La Porta et al., 1999; Morck \& Yeung, 2003; Peng \& 
Jiang, 2010). Although the relationship between ownership structures and firm performances has been widely studied in the literature, there are fewer studies about how ownership might influence corporate risk taking.

As noted above, agency theory with its consequent agency cost, is related to the ownership structure and the behavior of owners, which have a relevant impact on corporate risk taking. Speaking of ownership structure, the reference framework of agency theory assumes that managers are risk-averse and that the shareholders are risk neutral. In theory, therefore, in concentrated ownership structures with the presence of large shareholders, risk taking should be more evident than in managerial ownership firms, in which managers have a greater influence on the decisional process and tend to direct their choices towards less risky projects.

Utilizing the existence of private control benefits as the starting point, John et al. (2008) argue that large shareholders will assume a more conservative approach towards riskier projects in order to secure greater cash flows and higher private benefits. Major shareholders will be oriented towards riskier investments if they hold well-diversified and balanced portfolios. Therefore, shareholders who own non-diversified portfolios avoid projects with higher risk even if they have a positive net present value (Faccio et al., 2011). Investors who own shares of multiple companies show a higher propensity towards investing in risky projects compared to shareholders who have undiversified portfolios (Paligorova, 2010).

Faccio et al. (2011) study whether the diversification of large shareholders has an influence on corporate risk taking. Using a wide sample of European companies, both listed and non-listed, they find that diversification has a significant economic impact on risk taking. Companies with controlling shareholders who do not have a very diversified and balanced portfolio are more risk-averse and reluctant to realize riskier projects. They conclude that large shareholders influence and alter corporate risk taking in order to achieve their desired level of risk.

Boubaker et al. (2016) investigate a sample of French listed companies during the period 2003-2007 and find a negative relationship between large controlling shareholders and corporate risk taking. On the contrary, they note that when the number and power of multiple shareholders increase, there is an increase in risk taking. Multiple shareholders playing a monitoring role can counterbalance the conservative approach of controlling shareholder. Cole et al. (2011) have examined the implications of the separation of ownership and control with firms' risk taking attitudes. They discover that ownership structures have a significant impact on corporate risk taking, arguing that increased ownership concentration raises "the cost of risk-bearing services" that may lead to "less investment in risky projects".

One of the most widespread ownership models is the family model, where owners have a more cautious approach to risk due to the fact that one of their most relevant goals is the guaranteed transfer of business to the next generation (Anderson \& Reeb, 2003). The need to preserve the family assets to be transmitted from generation to generation could cause owners to participate in more risk-averse behaviors. The members of the board of directors are mostly chosen by the majority shareholder or controlling coalition.

Surprisingly, Anderson \& Reeb (2003) find that the presence of funder families, whom they assume to be undiversified investors, is associated with higher operating risk. In contrast, Amihud \& Lev (1981) find that investments which can reduce risk, such as diversifying acquisitions, are less likely when a large blockholder, whom they assume to be a more diversified investor, is present. In a more recent study, John et al. (2008) find that there is not a significant relationship between ownership concentration and corporate risk taking. Most of the family wealth is invested in the company, and, therefore, it may happen that the equity portfolio is poorly diversified, thus increasing the ownership's risk aversion regarding investing in riskier projects (Faccio et al., 2011; John et al., 2008).

The Italian Stock Market offers an interesting case study because most companies have a high ownership concentration that reaches, or exceeds, 50 percent of the common shares. As shown by La Porta et al. (1999), high ownership concentration and pyramids characterize Italian corporate governance. Prior studies have stated that high ownership concentration should be more common in those countries with lower shareholders protection because of the lack of ability of firms to sell equity to small investors when they are not significantly protected. Furthermore, the Italian business environment is characterized by the massive presence of family capitalism, with the above said features. Italian companies have large, controlling shareholders that can easily extract the private benefits of control at the expense of minority investors by controlling top managers' and board of directors' decisions (Moscariello et al., 2019; Nenova, 2003; Zingales, 1994). Given that owners exert stringent control over the company, they tend to avoid formal risk management practices, showing a less intense level of risk awareness. Therefore, it is reasonable to expect that the agency problem in Italian companies is more likely to be exacerbated by their ownership structure (Bianchi et al., 2010). Regarding ownership concentration, Fama and Jensen (1983) argue that a higher ownership concentration results in less risk taking as the wealth of these 
individuals is more concentrated and, therefore, less diversified. This implies that companies with a more dispersed structure would have a greater level of risk awareness. These predictions are consistent with the findings of several papers in the empirical literature which show that firms with less-concentrated ownership invest in higher-risk projects, such as R\&D and skill-intensive activities (Carlin \& Mayer, 2003; John et al., 2008; Laeven \& Levine, 2008; Wright et al., 1996). The comprehensive risk approach of the company is also related to the level of risk disclosure. Some agency theory research has shown that concentrated ownership structures tend to reduce the disclosure of risk information compared to those which are more dispersed (Brammer \& Pavelin, 2006; Eng \& Mak, 2003).

Hypothesis 1: Ownership concentration is negatively related to a firm's comprehensive/complete risk approach

\subsection{Institutional Investors as Shareholders}

Institutional investors may affect corporations' comprehensive risk approaches, and they are expected to have a positive effect on corporate risk taking and risk disclosure. The decision to invest a large proportion of their funds in a specific company is likely to reflect the intention to exert some form of control and monitoring, thus improving company governance. Institutional investors tend to buy significant stakes in the companies in which they invest (Meulbroek, 2001); and, given the size of their investments, they pay particular attention to the risk taking activity at target firms (Wright et al., 1996). According to agency theory, institutional investors, having substantial holdings of corporate equity, will monitor management to protect their investment and to ensure a good return (Shleifer \& Vishny, 1997). But, Cheng et al. (2011) and Della Croce et al. (2011) find that institutional investors may be interested in short-term profits and, therefore, encourage managers' risky behavior. Institutional investors may encourage boards to take higher risks to achieve higher returns by attempting to take advantage of growth opportunities (Erkens et al., 2012; Hansen \& Hill, 1991; Wright et al., 1996). Callen \& Fang (2013) also find that transient institutional investor ownership increases firm risk. Even the European Union stated that the recent financial crisis has undermined the assumption of institutional investors as responsible shareholders (European Parliament, 2010). Recent literature mostly supports the positive relationship between the percentage of substantial institutional holdings and firm risk.

The issue of whether institutional investors play an active or a passive role in the companies (Bhattacharya \& Graham, 2007; Dalton et al., 2003; Ferreira \& Matos, 2008) may be used to determine the extent to which institutional investors impact the level of risk awareness of the company. Moreover, different financial systems and cultural ideologies might lead to a different use of company resources. Moreover, investment funds typically are more likely to encourage a more proactive approach since shareholders are more likely to encourage managers to undertake riskier investment projects in order to maximize their short-term profits. Other investors, such as banks and insurance companies, may have other interests in companies and, therefore, play a more passive role with a stronger focus on corporate disclosure. In fact, they may be particularly sensitive to and careful about corporate risk if increased risk threatens their business or financial objectives (Bhattacharya \& Graham, 2007; Nguyen, 2011).

Institutional investors, as previously stated, can affect risk taking, but they also play a significant role in improving the level of corporate risk disclosure because an institutional owner, when simultaneously considered a minority shareholder, is bound to demand high-quality and more detailed information (Kane \& Velury, 2004). This demonstrates the higher level of attention paid by financial institutions to the global risk management system. Institutional investors are likely to be professional main blockholders who try to improve the quality of the firm's management. They will probably implement a stronger risk management policy, mitigating the Type II Agency Conflict, given the fact that institutional investors often have skills, abilities, and finances to help subsidiaries to engage in formal risk management actions. Therefore, the presence of an institutional investor in the ownership structure can have a positive effect on the comprehensive risk approach of firms through a reinforcement of the corporate risk disclosure. Furthermore, institutional investors are aware of deficits in risk reporting practice as reported by Solomon et al. Solomon et al. (2000).

Hypothesis 2: The presence of Institutional Investors in the ownership structure is positively related to a firm's comprehensive/complete risk approach.

\subsection{Presence of Shareholder Agreements}

Shareholders' agreements are a common corporate governance instrument within Italian listed companies, where the ultimate shareholder is supported by a coalition of blockholders (Bianchi \& Bianco, 2006). Volpin (2002) report that an agreement was in force in $15 \%$ of Italian listed firms. An agreement comprises a set of rules that drive the relationship between the agreement's subscribers. These rules usually protect shareholders' rights by, for example, requiring unanimous consent for important corporate decisions, restricting share negotiation, and 
giving shareholders the right of first refusal (Crisóstomo \& de Freitas Brandão, 2019). A shareholder agreement may be an instrument for surveilling a small group of large blockholders and to ease the use of private benefits of control by this group (Bianchi et al., 2001). An agreement can also mitigate conflicts among large shareholders, resulting in an improved corporate governance system (Attig et al., 2012). Prior studies have provided evidence of the positive effects of shareholder agreements on investment policy, investor protection, firm value, and firm reputation (Carvalhal, 2012; Maury \& Pajuste, 2005).

Italian listed companies represent an interesting field of study, as it is very common to have a coalition of large shareholders conjointly controlling one firm (Gianfrate, 2007). These shareholders are bounded by explicit agreements, called voting trusts or voting syndicates. Jiang \& Peng (2011) find that when the external governance mechanisms are ineffective, agreements between large shareholders become an effective internal mechanism for limiting the conflicts between dominant owners and minority shareholders. These shareholder coalitions tend to align the interests of the dominant owner with other shareholders (López-Iturriaga \& Santana-Martín, 2015). Prior studies find that the role of agreements is more important in countries with less liquid capital markets, such as Continental Europe, and in countries where legal and political factors constrain the market for corporate control relative to their US or UK counterparts (Bolton \& Thadden, 1998; Cuervo, 2002). In addition, by enhancing the power of other large shareholders challenges to the dominant owner's control, coalitions can also be an efficient control mechanism in countries with weak legal protections for minority shareholders (Bennedsen \& Wolfenzon, 2000; Volpin, 2002). According to Baglioni (2011), agreements are used to correct situations where the first owner's power is at one of the two extremes: either they are too low (leading to insufficient monitoring over managers and gridlocks in decision-making) or too high (enabling the first owner to extract large private benefits of control). The agreements between minority shareholders has become a useful tool for reducing the power of the largest shareholders in order to fend off the extraction of their private benefits.

It could be argued that shareholders' agreements between minority shareholders induce a lower level of ownership concentration when the first shareholder owns a significant part of the equity. Therefore, following the argument that a shareholder agreement can be an important instrument for constraining the power of one dominant large owner, shareholder agreements should produce a higher level of risk awareness as a consequence of a lower ownership concentration.

Hypothesis 3: Shareholder Agreements are positively related to a firm's comprehensive/complete risk approach.

In order to investigate the relationship between risk taking policies and disclosure, and the ownership structure of the companies, this research, as in premises, uses the framework of agency theory, so assuming that conflicts of interest arising between owners and managers due to a divergence of objectives and information asymmetry resulting from the separation of ownership and control. This conflict and information asymmetry would be mitigated by a wide disclosure about risks that help to ensure the efficiency of capital markets.

\section{Research Method and Data Collection}

This study examines the effect of different ownership characteristics on risk awareness for Italian listed firms in the year 2018. We included all industries (including banks, insurance companies, and so on) due to the fact that the, even if business risks may take place in different forms depending upon the nature of a company and the specific segment in which it develop the activity, the general risk awareness and the disclosure of the strategy to manage them has to be the same for all the companies. For that reason, no significant differences between industrial and financial companies in terms of risk awareness could be found. Different industries, in fact, could impact different areas of risk, but each company has a necessarily specific risk strategy and a proper level of risk awareness, that we measure as follows.

The financial data are collected from annual reports and obtained from the AIDA bureau van dijk database, whereas we hand-collected the 2018 ownership data from historical shareholder information in the AIDA bureau van dijk.

Out of the entire collection of 376 Italian listed firms, we excluded those with missing data, thus arriving at a final sample of 233.

See Appendix A for variables definition.

To test our hypotheses on the whole database of Italian listed firms, we run the following regression models:

$$
\begin{gathered}
\text { Risk Awareness Indicator }=\beta_{0}+\beta_{1} \text { Ownership }+\beta_{2} \text { Size }+\beta_{3} R O A+\beta_{4} \text { DebtRatio }+\beta_{5} \text { Employees }+e \\
\text { Risk Awareness Indicator }=\beta_{0}+\beta_{1} \text { InstitutionalInvestor }+\beta_{2} \text { Size }+\beta_{3} R O A+\beta_{4} \text { DebtRatio }+\beta_{5} \text { Employees }+e(2)
\end{gathered}
$$




$$
\begin{gathered}
\text { Risk Awareness Indicator }=\beta_{0}+\beta_{1} \text { ShareholdersAgreement }+\beta_{2} \text { Size }+ \\
\beta_{5} \text { Employees }+e
\end{gathered}
$$

Risk Awareness is measured considering both risk management actions implemented by companies and also risk information disclosed in firms' public reports. We measure the Risk Awareness indicator by calculating a score from 0 to 10 .

Using an approach spread in literature (Gray et al., 1995) an equal weighting/unweighted index approach is adopted in scoring the RDI. The index assumes that each item of disclosure is equally important. According to this approach, this simple measurement approach is considered most appropriate as it is less subjective and less judgmental (Gray et al., 1995). After finalizing the risk disclosure index, a scoring sheet is developed to assess the extent of voluntary risk disclosure. The index was composed mixing what suggested by Linsley \& Shrives (2006), Akhigbe \& Martin (2008), and Nur Probohudono et al. (2013).

Using all public information and public documents on the company's website, we check 10 different issues, considering them as indicators of high-risk awareness by the firms. We first confirm for the presence of the risk committee; then, we attempt to understand whether the company has appointed an individual to guarantee the quality of the Internal Control System. Moreover, we check for the presence of the Chief Risk Officer (CRO) or an employee that serves as a risk manager. Another risk awareness is represented by an "ad hoc" section of the internal control system the corporate governance report, which takes into account its extensiveness. We also verify the implementation of a centralized risk strategy in business groups. References to the International CoSO Framework and the presence of a risk management function are other significant indicators. Lastly, we check if the firms have a risk appetite framework and if they have the Internal Control over Financial Reporting.

Checking each of the above-mentioned questions, the highest score equal to 10 in case of the presence of all of them; 10 points mean that the firms have high attention to the risk.

Ownership is measured by the percentage of equity owned by major shareholders.

In line with previous literature, the control variables used in the study are size, as the natural logarithm of total assets at the end of the fiscal year, the return on assets (ROA), debt ratio and the number of employees. We consider both size and employees as proxies for firm resources. Furthermore, previous studies suggest that financial structure and performance may affect a firm's risk taking orientation. Thus, we consider debt ratio and ROA (Ghosh et al., 2007; O’Brien, 2003; Su \& Lee, 2013).

\section{Research Results and Discussions}

Looking at descriptive results, Table 1 show descriptive statistics.

Table 1. Descriptive statistics

\begin{tabular}{llllll}
\hline Dependent variables & $\mathbf{N}$ & Min. & Max. & Mean & SD \\
\hline Risk Awareness Indicator & 233 & 0.000 & 10.000 & 5.369 & 2.009 \\
Independent variables & $\mathbf{N}$ & Min. & Max. & Mean & SD \\
Ownership & 233 & 3.676 & 100.000 & 48.452 & 22.184 \\
Institutional Investor & 233 & 0.000 & 1.000 & 0.430 & 0.496 \\
Shareholders Agreement & 233 & 0.000 & 1.000 & 0.300 & 0.458 \\
Control variables & $\mathbf{N}$ & Min. & Max. & Mean & SD \\
Size & 233 & 10.200 & 26.000 & 20.279 & 2.224 \\
ROA & 233 & -6.200 & 24.900 & 0.153 & 1.729 \\
DebtRatio & 233 & 0.000 & 7.300 & 0.614 & 0.603 \\
Employees & 233 & 0 & $131,358.000$ & $5,041.720$ & $13,421.770$ \\
\hline
\end{tabular}

The mean value of the risk awareness indicator is equal to 5.37, with a maximum of 10 and a minimum level equal to 0 . This confirms that in the Italian scenario, some firms are the best in their class, while others pay no attention to risk. Regarding the independent variables, Italian listed companies have a major shareholder that owns at least $3.68 \%$ of the share with a maximum level of the total shares of the company being $100 \%$ (meaning value is equal to $48.45 \%$ ). The natural logarithm of total asset, as a proxy of dimension, has a mean value equal to 20.279 , with a standard deviation equal to 2.224 . ROA signals that Italian listed firms have a return on their investment of $15.3 \%$, on average; they also have a high debt ratio, highlighting that, on average, $61.4 \%$ of the total asset are covered by third party equity. Lastly, two Italian listed companies have no employees, while the 
highest number workers is equal to $131,358.000$.

Table 2 illustrates the univariate correlation between variables.

Table 2. Pearson correlation matrix

\begin{tabular}{|c|c|c|c|c|c|c|c|c|c|}
\hline & & 1 & 2 & 3 & 4 & 5 & 6 & 7 & 8 \\
\hline 1 & Risk Awareness Indicator & 1.000 & & & & & & & \\
\hline 2 & Ownership & -0.191 & 1.000 & & & & & & \\
\hline 3 & Institutional Investor & 0.256 & - & 1.000 & & & & & \\
\hline 4 & Shareholders Agreement & 0.220 & - & - & 1.000 & & & & \\
\hline 5 & Size & 0.485 & -0.151 & 0.286 & -0.056 & 1.000 & & & \\
\hline 6 & ROA & 0.076 & -0.139 & 0.109 & 0.063 & -0.076 & 1.000 & & \\
\hline 7 & Debt Ratio & 0.007 & 0.106 & 0.001 & 0.092 & -0.152 & -0.098 & 1.000 & \\
\hline 8 & Employees & 0.301 & -0.158 & 0.246 & -0.090 & 0.432 & -0.025 & -0.001 & 1.000 \\
\hline
\end{tabular}

Note. Correlation is measured by Pearson coefficients. Bold items are coefficients significant at a level of $5 \%$.

As expected, Ownership is negatively correlated with Risk Awareness Indicator. Despite the variables not being highly correlated, we check the VIF indicator that remains well below 5, thus we conclude that there are no problems of multicollinearity.

Looking at the multivariate regression results, we confirm our first and second hypotheses. In detail, Table 3 summarizes the results of HP1 in detail.

Table 3. Multivariate Analysis - HP1: Ownership structure as a determinant of risk taking

\begin{tabular}{lll}
\hline & Coefficient & p-value \\
\hline Ownership & $\mathbf{- 0 . 0 0 9}$ & $\mathbf{0 . 0 7 7}$ \\
Size & 0.409 & $<0.001$ \\
ROA & 0.125 & 0.063 \\
DebtRatio & 0.323 & 0.095 \\
Employees & 0.00001 & 0.149 \\
Intercept & -2.760 & 0.026 \\
$\mathrm{R}^{2}$ & 0.276 & \\
Number of observation & 233 & \\
\hline
\end{tabular}

The regression is significant, with an overall R-square of 0.276 , which is an acceptable value in the accounting studies (Marchini et al., 2018). Focusing on the first hypothesis the coefficient of Ownership is negative and significant (coefficient $=-0.009$; -value $=0.077$ ) meaning that the relationship between the ownership concentration and the level of risk awareness has a negative trend. In other words, this result shows that the highest percentage of share in the hands of the major shareholder causes the lowest attention to be paid to firms' risk.

This relevant finding supports the idea that concentrate ownership may create agency conflicts (Dyck \& Zingales, 2004; Fama \& Jensen, 1983; Shleifer \& Vishny, 1997) and that controlling shareholders can easily extract private benefits of control at the expense of minority investors (Moscariello et al., 2019; Nenova, 2003; Zingales, 1994). From this perspective, our results confirms the swath of literature that supports the idea that concentration is closely related to more risk taking (Amihud \& Lev, 1981; Anderson \& Reeb, 2003) and, in light of our hypothesis, it reduces the risk awareness (Brammer \& Pavelin, 2006; Eng \& Mak, 2003). These findings are probably due to the fact that the low status of minorities prevents them (or their delegates) from carefully monitoring this area.

Table 4 shows findings related to HP2. 
Table 4. Multivariate Analysis - H2: Institutional Investors as determinant of risk taking

\begin{tabular}{lll}
\hline & Coefficient & p-value \\
\hline InstitutionalInvestor & $\mathbf{0 . 3 8 8}$ & $\mathbf{0 . 1 0 3}$ \\
Size & 0.398 & $<0.001$ \\
ROA & 0.127 & 0.059 \\
DebtRatio & 0.280 & 0.147 \\
Employees & 0.00001 & 0.158 \\
Intercept & -3.118 & 0.010 \\
$\mathrm{R}^{2}$ & 0.274 & \\
Number of observation & 233 & \\
\hline
\end{tabular}

Again, in this case, we demonstrated a satisfactory R-square.

As stated in the second hypothesis, the presence of institutional investors, as actors with high standards of expertise who have a high awareness of the firms' risk approaches, increases risk awareness. The coefficient of InstitutionalInvestor determinants of risk taking, is, in fact, positive and significant (coefficient $=0.388$; $\mathrm{p}$-value $=0.103$ ), meaning that the presence of at least 20 percent institutional investors increases the risk awareness of the firm. In other words, this result shows that the presence of banks, insurance companies, mutual funds, hedge funds and so on serves as a guarantee for the possession of greater risk awareness.

These results confirm the current literature's finding regarding the role of institutional investors as safeguards. What is more, given the relevance of their investments, our findings confirm that they pay particular attention to the risk taking activity at target firms (Wright et al., 1996). As in Bhattacharya \& Graham (2007) and Nguyen (2011), we confirm that they are particularly sensitive to corporate risk. Institutional investors play a crucial role in positively influencing both risk management actions as well as risk disclosure along with an increased level of risk awareness. Institutional investors can affect risk taking, but they also play a significant role in improving the level of corporate risk disclosure because an institutional owner, when considered a minority shareholder, demands high-quality and more detailed information (Kane \& Velury, 2004). Thus, we confirm that the presence of an institutional investor in the ownership structure can have a positive effect on the comprehensive risk approach of the firm along with a reinforcement of the corporate risk disclosure.

Lastly, in table 5 we present results on HP3.

Table 5. Multivariate Analysis - H3: Shareholders agreements as determinants of risk taking

\begin{tabular}{lll}
\hline & Coefficient & p-value \\
\hline ShareholdersAgreement & $\mathbf{0 . 1 8 4}$ & $\mathbf{0 . 4 7 0}$ \\
Size & 0.432 & $<0.001$ \\
ROA & 0.144 & 0.033 \\
DebtRatio & 0.304 & 0.121 \\
Employees & 0.00001 & 0.107 \\
Intercept & -3.729 & 0.002 \\
$\mathrm{R}^{2}$ & 0.276 & \\
Number of observation & 233 & \\
\hline
\end{tabular}

Despite our consideration of the presence of a shareholder's agreement, as a sort of proxy of ownership concentration, our results do not confirm the third hypothesis. In particular, the p-value of ShareholdersAgreement variable indicates no significant relationship between risk awareness and the presence of an agreement between shareholders.

We interpret this insignificant result as a possible distinction between firms with a high level of ownership concentration and companies in which a shareholders' agreement is in place. Moreover, a further step of the research could entail in-depth analysis of the percentage of shares included in the agreement.

\section{Conclusions}

The complex socio-economic climate in which companies engage in their activity, requires them to concretely implement functions and procedures relating to risk awareness and its aftermath (Caldarelli et al., 2016). Also, McMullen \& Shepherd (2006) and Alchian (1950) underline the importance of exploring and properly managing 
risks in each category, even more so in this unpredictable and complex time in which we find ourselves.

Moreover, practitioners underline the marginal role have played by the risk management up until now in the strategic view of the company. It appears, in fact, that ad hoc actions have been simply carried out only to contain the uncertainty of specific activities; in other words, risk awareness was never really integrated and shared in the holistic overview of the company's perspective. The combination of risks to which companies are exposed is as complex as the enterprise system, and it requires a professional and profound approach (OECD, 2014).

The consequences of the global financial crisis together with several significant corporate scandals shed light on the importance of having good procedures and a strategic view of risk management. Important questions are raised about what type of corporate governance would be useful for surveilling management activities and, consequently, for reducing the connected risks. The lack of efficiency and the capacity to detect potential risky operations and to define an aware approach to risk management procedures has exposed big companies to litigation and business failure. Furthermore, the global financial crisis exposes not only a lack of good and widely adopted risk management policies but also exposes a serious problem concerning risk information and disclosure.

In light of the increased relevance of the topic, and, considering the greater attention to firms' risk management disclosure, this research provides evidence on the relationship between risk taking and ownership structure. Our results confirm that dispersed ownership and the presence of investors with the role of "guarantors" such as that of institutional investors help to improve firms' risk awareness.

This study contributes to the current literature in two ways. First, it adds knowledge to the subject of ownership structure and its relationship with risk taking, which, unlike that which concerns the board of directors' characteristics, has been poorly investigated up until now. Secondly, it empirically analyzes the link between governance characteristics and a specific feature of risk taking, namely risk information and disclosure, which firms provide to the investor and capital markets.

Regulators could also consider these results in their attempts to enhance policies related to firms' and corporations' risk disclosure. For example, they could request restrictive policies for companies with concentrated ownership that are less proactive and fair in the implementation of risk management practices. Likewise, practitioners may benefit from these findings. They could help less pro-active companies to develop high-quality risk management systems and complete disclosure.

We recognize that our study may be limited due to the single year analyzed (and, thus, the limited observations considered in the analysis) and also from the measure of Risk Awareness we proposed. Although our results are meaningful, we acknowledge that they are less generalizable. Moreover, different measures of risk awareness may lead to different results, rather than to a confirmation of our findings.

These limitations and unexplored questions justify the need for further investigation. Future steps may include the study of a five-year-time frame in order to capture significant changes in the ownership structure of Italian firms. Moreover, similar analysis in other European countries with less concentrated ownership could highlight, or not, similar results to those proposed in the Italian case study. In addition, the consideration of some contextual variables (e.g., shareholder legal protection) could help to better capture the relationship between risk awareness and ownership characteristics.

\section{References}

Abraham, S., \& Cox, P. (2007). Analysing the determinants of narrative risk information in UK FTSE 100 annual reports. The British Accounting Review, 39(3), 227-248. https://doi.org/10.1016/j.bar.2007.06.002

Abraham, S., \& Shrives, P. J. (2014). Improving the relevance of risk factor disclosure in corporate annual reports. The British Accounting Review, 46(1), 91-107. https://doi.org/10.1016/j.bar.2013.10.002

Acemoglu, D., \& Zilibotti, F. (1997). Was Prometheus Unbound by Chance? Risk, Diversification, and Growth. Journal of Political Economy, 105(4), 709-751. https://doi.org/10.1086/262091

Adams, R. B., \& Ferreira, D. (2009). Women in the boardroom and their impact on governance and performance. Journal of Financial Economics, 94(2), 291-309. https://doi.org/10.1016/j.jfineco.2008.10.007

Adams, R., \& Ferreira, D. (2010). Moderation in Groups: Evidence from Betting on Ice Break-ups in Alaska. The Review of Economic Studies, 77(3), 882-913. https://doi.org/10.1111/j.1467-937X.2009.00594.x

Agrawal, A., \& Knoeber, C. R. (1996). Firm Performance and Mechanisms to Control Agency Problems between Managers and Shareholders. The Journal of Financial and Quantitative Analysis, 31(3), 377-397. JSTOR. 
https://doi.org/10.2307/2331397

Aguilera, R. V., \& Jackson, G. (2003). The Cross-National Diversity of Corporate Governance: Dimensions and Determinants. Academy of Management Review, 28(3), 447-465. https://doi.org/10.5465/amr.2003.10196772

Akhigbe, A., \& Martin, A. D. (2008). Influence of disclosure and governance on risk of US financial services firms following Sarbanes-Oxley q. 12.

Alchian, A. A. (1950). Uncertainty, Evolution, and Economic Theory. Journal of Political Economy, 58(3), 211-221. https://doi.org/10.1086/256940

Amihud, Y., \& Lev, B. (1981). Risk Reduction as a Managerial Motive for Conglomerate Mergers. The Bell Journal of Economics, 12(2), 605-617. https://doi.org/10.2307/3003575

Anderson, R. C., \& Reeb, D. M. (2003). Founding-Family Ownership and Firm Performance: Evidence from the S\&P 500. The Journal of Finance, 58(3), 1301-1328. https://doi.org/10.1111/1540-6261.00567

Attig, N., Cleary, S., El Ghoul, S., \& Guedhami, O. (2012). Institutional investment horizon and investment-cash flow sensitivity. Journal of Banking \& Finance, 36(4), 1164-1180. https://doi.org/10.1016/j.jbankfin.2011.11.015

Baglioni, A. (2011). Shareholders' agreements and voting power: Evidence from Italian listed firms. Applied Economics, 43(27), 4043-4052. https://doi.org/10.1080/00036841003781494

Barber, B. M., \& Odean, T. (2001). Boys will be boys: Gender, overconfidence, and common stock investment. The quarterly journal of economics, 116(1), 261-292. https://doi.org/10.2139/ssrn.139415

Baumol, W. J., Litan, R. E., \& Schramm, C. J. (2007). Good Capitalism, Bad Capitalism, and the Economics of Growth and Prosperity (SSRN Scholarly Paper ID 985843). Social Science Research Network. https://doi.org/10.2139/ssrn.985843

Bennedsen, M., \& Wolfenzon, D. (2000). The balance of power in closely held corporations. Journal of Financial Economics, 58(1), 113-139. https://doi.org/10.1016/S0304-405X(00)00068-4

Beretta, S., \& Bozzolan, S. (2004). A framework for the analysis of firm risk communication. The International Journal of Accounting, 39(3), 265-288. https://doi.org/10.1016/j.intacc.2004.06.006

Bhattacharya, P. S., \& Graham, M. (2007). Institutional Ownership and Firm Performance: Evidence from Finland (SSRN Scholarly Paper ID 1000092). Social Science Research Network. https://doi.org/10.2139/ssrn.1000092

Bianchi, M., \& Bianco, M. (2006). Italian Corporate Governance in the Last 15 Years: From Pyramids to Coalitions? SSRN Electronic Journal. https://doi.org/10.2139/ssrn.952147

Bianchi, M., Bianco, M., \& Enriques, L. (2001). Pyramidal Groups and the Separation Between Ownership and Control in Italy. In The Control of Corporate Europe. Oxford University Press. https://www.oxfordscholarship.com/view/10.1093/0199257531.001.0001/acprof-9780199257539-chapter-6

Bianchi, M., Bianco, M., \& Enriques, L. (2010). Pyramidal Groups and the Separation Between Ownership and Control in Italy (SSRN Scholarly Paper ID 293882). Social Science Research Network. https://doi.org/10.2139/ssrn.293882

Bolton, P., \& Thadden, E.-L. V. (1998). Blocks, Liquidity, and Corporate Control. The Journal of Finance, 53(1), 1-25. https://doi.org/10.1111/0022-1082.15240

Boubaker, S., Nguyen, P., \& Rouatbi, W. (2016). Multiple Large Shareholders and Corporate Risk-taking: Evidence from French Family Firms. European Financial Management, 22(4), 697-745. https://doi.org/10.1111/eufm.12086

Brammer, S. J., \& Pavelin, S. (2006). Corporate Reputation and Social Performance: The Importance of Fit. Journal of Management Studies, 43(3), 435-455. https://doi.org/10.1111/j.1467-6486.2006.00597.x

Brick, I. E., \& Chidambaran, N. K. (2008). Board monitoring, firm risk, and external regulation. Journal of Regulatory Economics, 33(1), 87-116. https://doi.org/10.1007/s11149-007-9045-9

Caldarelli, A., Fiondella, C., Maffei, M., \& Zagaria, C. (2016). Managing risk in credit cooperative banks: Lessons from a case study. Management Accounting Research, 32, 1-15. https://doi.org/10.1016/j.mar.2015.10.002 
Callen, J. L., \& Fang, X. (2013). Institutional investor stability and crash risk: Monitoring versus short-termism? Journal of Banking \& Finance, 37(8), 3047-3063. https://doi.org/10.1016/j.jbankfin.2013.02.018

Campbell, J. L., Chen, H., Dhaliwal, D. S., Lu, H., \& Steele, L. B. (2014). The information content of mandatory risk factor disclosures in corporate filings. Review of Accounting Studies, 19(1), 396-455. https://doi.org/10.1007/s11142-013-9258-3

Carlin, W., \& Mayer, C. (2003). Finance, investment, and growth. Journal of Financial Economics, 69(1), 191-226. https://doi.org/10.1016/S0304-405X(03)00112-0

Carvalhal, A. (2012). Do shareholder agreements affect market valuation?: Evidence from Brazilian listed firms. Journal of Corporate Finance, 18(4), 919-933. https://doi.org/10.1016/j.jcorpfin.2012.04.003

Charness, G., \& Gneezy, U. (2012). Strong Evidence for Gender Differences in Risk Taking. Journal of Economic Behavior \& Organization, 83(1), 50-58. https://doi.org/10.1016/j.jebo.2011.06.007

Cheng, J., Elyasiani, E., \& Jia, J. (Jane). (2011). Institutional Ownership Stability and Risk Taking: Evidence From the Life-Health Insurance Industry. Journal of Risk and Insurance, 78(3), 609-641. https://doi.org/10.1111/j.1539-6975.2011.01427.x

Cheng, S. (2008). Board size and the variability of corporate performance. Journal of Financial Economics, 87(1), 157-176. https://doi.org/10.1016/j.jfineco.2006.10.006

Claessens, S., Djankov, S., \& Lang, H. (1999). The Separation of Ownership and Control in East Asian Corporations. Journal of Financial https://doi.org/10.1016/S0304-405X(00)00067-2

Cole, C. R., He, E., McCullough, K. A., \& Sommer, D. W. (2011). Separation of Ownership and Management: Implications for Risk-Taking Behavior. Risk Management and Insurance Review, 14(1), 49-71. https://doi.org/10.1111/j.1540-6296.2010.01192.x

Core, J. E. (2001). A review of the empirical disclosure literature: Discussion. Journal of Accounting and Economics, 31(1), 441-456. https://doi.org/10.1016/S0165-4101(01)00036-2

Crisóstomo, V. L., \& de Freitas Brandão, I. (2019). The ultimate controlling owner and corporate governance in Brazil. Corporate Governance: The International Journal of Business in Society, 19(1), 120-140. https://doi.org/10.1108/CG-01-2018-0043

Crovini, C., Ossola, G., \& Marchini, P. L. (2018). Cyber Risk. The New Enemy for Risk Management in the Age of Globalisation. MANAGEMENT CONTROL, 2018/2 Suppl. (2 Suppl.), 135-155. https://doi.org/10.3280/MACO2018-SU2007

Cuervo, A. (2002). Corporate Governance Mechanisms: A plea for less code of good governance and more market control. Corporate Governance: An International Review, 10(2), 84-93. https://doi.org/10.1111/1467-8683.00272

Dalton, D. R., Daily, C. M., Certo, S. T., \& Roengpitya, R. (2003). Meta-Analyses of Financial Performance and Equity: Fusion or Confusion? The Academy of Management Journal, 46(1), 13-26. https://doi.org/10.2307/30040673

De Long, J. B., \& Summers, L. H. (1991). Equipment Investment and Economic Growth: The Quarterly Journal of Economics $\quad$ Oxford Academic. Retrieved from https://academic.oup.com/qje/article-abstract/106/2/445/1905455?redirectedFrom=fulltext

De Marco, F. (2019). Bank Lending and the European Sovereign Debt Crisis. Journal of Financial and Quantitative Analysis, 54(1), 155-182. https://doi.org/10.1017/S0022109018000510

DeAngelo, H., \& DeAngelo, L. (2000). Controlling stockholders and the disciplinary role of corporate payout policy: A study of the Times Mirror Company. Journal of Financial Economics, 56(2), 153-207. https://doi.org/10.1016/S0304-405X(00)00039-8

Della Croce, R., Stewart, F., \& Yermo, J. (2011). Promoting longer-term investment by institutional investors: Selected issues and policies. FINANCIAL MARKET TRENDS, 2011(1), 20. https://doi.org/10.1787/fmt-2011-5kg55b0z1ktb.

Deloitte. (2012). Risk assessment in practice, Deloitte CIS, Risk, ERM, Governance, Compliance, Serives. Deloitte Russia. $\quad$ Retrieved from https://www2.deloitte.com/ru/en/pages/governance-risk-and-compliance/articles/risk-assessment-in-practice 
.html

Deumes, R. (2008). Corporate Risk Reporting: A Content Analysis of Narrative Risk Disclosures in Prospectuses. The Journal of Business Communication (1973), 45(2), 120-157. https://doi.org/10.1177/0021943607313992

Dobler, M. (2008). Incentives for risk reporting-A discretionary disclosure and cheap talk approach. The International Journal of Accounting, 43(2), 184-206. https://doi.org/10.1016/j.intacc.2008.04.005

Dobler, M., Lajili, K., \& Zéghal, D. (2011). Attributes of Corporate Risk Disclosure: An International Investigation in the Manufacturing Sector. Journal of International Accounting Research, 10(2), 1-22. https://doi.org/10.2308/jiar-10081

Dyck, A., \& Zingales, L. (2004). Private Benefits of Control: An International Comparison. The Journal of Finance, 59(2), 537-600. https://doi.org/10.1111/j.1540-6261.2004.00642.x

Elshandidy, T., \& Neri, L. (2015). Corporate Governance, Risk Disclosure Practices, and Market Liquidity: Comparative Evidence from the UK and Italy. Corporate Governance: An International Review, 23. https://doi.org/10.1111/corg.12095

Eng, L. L., \& Mak, Y. T. (2003). Corporate governance and voluntary disclosure. Journal of Accounting and Public Policy, 22(4), 325-345. https://doi.org/10.1016/S0278-4254(03)00037-1

Erkens, D. H., Hung, M., \& Matos, P. (2012). Corporate governance in the 2007-2008 financial crisis: Evidence from financial institutions worldwide. Journal of Corporate Finance, 18(2), 389-411. https://doi.org/10.1016/j.jcorpfin.2012.01.005

Faccio, M., Lang, H., \& Young, L. (2001). Dividends and Expropriation. American Economic Review, 91, 54-78. https://doi.org/10.1257/aer.91.1.54

Faccio, M., Marchica, M. T., \& Mura, R. (2011). Large Shareholder Diversification and Corporate Risk-Taking. Review of Financial Studies, 24(11), 3601-3641. https://doi.org/10.1093/rfs/hhr065

Faccio, M., Marchica, M. T., \& Mura, R. (2016). CEO gender, corporate risk-taking, and the efficiency of capital allocation. Journal of Corporate Finance, 39, 193-209. https://doi.org/10.1016/j.jcorpfin.2016.02.008

Fama, E. F. (1980). Agency Problems and the Theory of the Firm. Journal of Political Economy, 88(2), 288-307. JSTOR.

Fama, E. F., \& Jensen, M. C. (1983). Separation of Ownership and Control. The Journal of Law and Economics, 26(2), 301-325. https://doi.org/10.1086/467037

Ferreira, M. A., \& Laux, P. A. (2007). Corporate Governance, Idiosyncratic Risk, and Information Flow. The Journal of Finance, 62(2), 951-989. https://doi.org/10.1111/j.1540-6261.2007.01228.x

Ferreira, M. A., \& Matos, P. (2008). The colors of investors' money: The role of institutional investors around the world. Journal of Financial Economics, 88(3), 499-533. https://doi.org/10.1016/j.jfineco.2007.07.003

Fuller, J., \& Jensen, M. C. (2002). Just Say No to Wall Street: Putting a Stop to the Earnings Game (SSRN Scholarly Paper ID 297156). Social Science Research Network. https://doi.org/10.2139/ssrn.297156

Ghosh, A., Moon, D., \& Tandon, K. (2007). CEO Ownership and Discretionary Investments. Journal of Business Finance \& Accounting, 34(5-6), 819-839. https://doi.org/10.1111/j.1468-5957.2007.02011.x

Gianfrate, G. (2007). What Do Shareholders? Coalitions Really Want? Evidence from Italian voting trusts. Corporate Governance: An International Review, 15(2), 122-132. https://doi.org/10.1111/j.1467-8683.2007.00549.x

Gray, R., Kouhy, R., \& Lavers, S. (1995). Corporate social and environmental reporting: A review of the literature and a longitudinal study of UK disclosure. Accounting, Auditing \& Accountability Journal, 8(2), 47-77. https://doi.org/10.1108/09513579510146996

Hansen, G. S., \& Hill, C. W. L. (1991). Are institutional investors myopic? A time-series study of four technology-driven industries. Strategic Management Journal, 12(1), 1-16. https://doi.org/10.1002/smj.4250120102

Healy, P. M., \& Palepu, K. G. (2001). Information asymmetry, corporate disclosure, and the capital markets: A review of the empirical disclosure literature. Journal of Accounting and Economics, 31(1), 405-440. https://doi.org/10.1016/S0165-4101(01)00018-0 
Hutton, A. (2004). Beyond Financial Reporting An Integrated Approach to Disclosure. Journal of Applied Corporate Finance, 16(4), 8-16. https://doi.org/10.1111/j.1745-6622.2004.00003.x

IIF. (2009). Reform in the Financial Services Industry: Strengthening Practices for a More Stable System : the Report of the IIF Steering Committee on Implementation (SCI). Institute of international finance.

Jensen, M. C. (1993). The Modern Industrial Revolution, Exit, and the Failure of Internal Control Systems. The Journal of Finance, 48(3), 831-880. https://doi.org/10.1111/j.1540-6261.1993.tb04022.x

Jensen, M. C., \& Meckling, W. H. (1976). Theory of the firm: Managerial behavior, agency costs and ownership structure. Journal of Financial Economics, 3(4), 305-360. https://doi.org/10.1016/0304-405X(76)90026-X

Jia, J., Munro, L., \& Buckby, S. (2016). A finer-grained approach to assessing the "quality" ("quantity" and "richness") of risk management disclosures. Managerial Auditing Journal, 31(8/9), 770-803. https://doi.org/10.1108/MAJ-12-2014-1135

Jiang, Y., \& Peng, M. W. (2011a). Are family ownership and control in large firms good, bad, or irrelevant? Asia Pacific Journal of Management, 28(1), 15-39. https://doi.org/10.1007/s10490-010-9228-2

Jiang, Y., \& Peng, M. W. (2011b). Principal-principal conflicts during crisis. Asia Pacific Journal of Management, 28(4), 683-695. https://doi.org/10.1007/s10490-009-9186-8

John, K., Litov, L., \& Yeung, B. (2008). Corporate Governance and Risk-Taking. The Journal of Finance, 63(4), 1679-1728. https://doi.org/10.1111/j.1540-6261.2008.01372.x

Jorgensen, B. N., \& Kirschenheiter, M. T. (2003). Discretionary Risk Disclosures. The Accounting Review, 78(2), 449-469. JSTOR.

Jorion, P. (2002). How Informative Are Value-at-Risk Disclosures? The Accounting Review, 77(4), 911-931. https://doi.org/10.2308/accr.2002.77.4.911

Kane, G. D., \& Velury, U. (2004). The role of institutional ownership in the market for auditing services: An empirical investigation. Journal of Business Research, 57(9), 976-983. https://doi.org/10.1016/S0148-2963(02)00499-X

Kanodia, C., \& Lee, D. (1998). Investment and Disclosure: The Disciplinary Role of Periodic Performance Reports. Journal of Accounting Research, 36(1), 33-55. https://doi.org/10.2307/2491319

Karamanou, I., \& Vafeas, N. (2005). The Association between Corporate Boards, Audit Committees, and Management Earnings Forecasts: An Empirical Analysis. Journal of Accounting Research, 43(3), 453-486. https://doi.org/10.1111/j.1475-679X.2005.00177.x

Kravet, T., \& Muslu, V. (2013). Textual risk disclosures and investors' risk perceptions. Review of Accounting Studies, 18(4), 1088-1122. https://doi.org/10.1007/s11142-013-9228-9

La Porta, R., Lopez-De-Silanes, F., \& Shleifer, A. (1999). Corporate Ownership Around the World. The Journal of Finance, 54(2), 471-517. https://doi.org/10.1111/0022-1082.00115

La Porta, R., Lopez-De-Silanes, F., Shleifer, A., \& Vishny, R. (2002). Investor Protection and Corporate Valuation. The Journal of Finance, 57(3), 1147-1170. https://doi.org/10.1111/1540-6261.00457

Laeven, L., \& Levine, R. (2008). Complex Ownership Structures and Corporate Valuations. The Review of Financial Studies, 21(2), 579-604. https://doi.org/10.1093/rfs/hhm068

Lam, J. (2014). Enterprise Risk Management: From Incentives to Controls. John Wiley \& Sons.

Lambert, R. A. (2001). Contracting Theory and Accounting (SSRN Scholarly Paper ID 235800). Social Science Research Network. https://doi.org/10.2139/ssrn.235800

Lehuede, H. J., Kirkpatrick, G., \& Teichmann, D. (2012). Corporate Governance Lessons from the Financial Crisis. SSRN Electronic Journal. https://doi.org/10.2139/ssrn.2393978

Levi, M., Li, K., \& Zhang, F. (2014). Director gender and mergers and acquisitions. Journal of Corporate Finance, 28, 185-200. https://doi.org/10.1016/j.jcorpfin.2013.11.005

Lewellyn, K. B., \& Muller-Kahle, M. I. (2012). CEO Power and Risk Taking: Evidence from the Subprime Lending Industry. Corporate Governance: An International Review, 20(3), 289-307. https://doi.org/10.1111/j.1467-8683.2011.00903.x

Linsley, P., \& Shrives, P. (2006). Risk Reporting: A Study of Risk Disclosures in the Annual Reports of UK Companies. The British Accounting Review, 38, 387-404. https://doi.org/10.1016/j.bar.2006.05.002 
Lipton, M., \& Lorsch, J. W. (1992). A Modest Proposal for Improved Corporate Governance. The Business Lawyer, 48(1), 59-77.

López-Iturriaga, F. J., \& Santana-Martín, D. J. (2015). Do Shareholder Coalitions Modify the Dominant Owner's Control? The Impact on Dividend Policy: Shareholder Coalitions and Dividends. Corporate Governance: An International Review, 23(6), 519-533. https://doi.org/10.1111/corg.12126

Marchini, P. L., Mazza, T., \& Medioli, A. (2018). The impact of related party transactions on earnings management: Some insights from the Italian context. Journal of Management and Governance, 22(4), 981-1014. https://doi.org/10.1007/s10997-018-9415-y

Martikainen, M., Kinnunen, J., Miihkinen, A., \& Troberg, P. (2015). Board's financial incentives, competence, and firm risk disclosure: Evidence from Finnish index listed companies. Journal of Applied Accounting Research, 16(3), 333-358. https://doi.org/10.1108/JAAR-10-2014-0117

Mathew, S. (2013). Board Composition and Risk-taking in UK firms. European Financial Management Annual Conference, ICMA Centre-Henley Business School, University of Reading, UK.

Maury, B., \& Pajuste, A. (2005). Multiple large shareholders and firm value. Journal of Banking \& Finance, 29(7), 1813-1834. https://doi.org/10.1016/j.jbankfin.2004.07.002

McCrae, M., \& Balthazor, L. (2000). Integrating Risk Management into Corporate Governance: The Turnbull Guidance. Risk Management, 2(3), 35-45. https://doi.org/10.1057/palgrave.rm.8240057

McMullen, J., \& Shepherd, D. (2006). Entrepreneurial Action and the Role of Uncertainty in the Theory of Entrepreneur. Academy of Management Review, 31. https://doi.org/10.5465/AMR.2006.19379628

Melnyk, S. A., Bititci, U., Platts, K., Tobias, J., \& Andersen, B. (2014). Is performance measurement and management fit for the future? Management Accounting Research, 25(2), 173-186. https://doi.org/10.1016/j.mar.2013.07.007

Meulbroek, L. K. (2001). The Efficiency of Equity-Linked Compensation: Understanding the Full Cost of Awarding Executive Stock Options. Financial Management, 30(2), 5-44. https://doi.org/10.2307/3666404

Miihkinen, A. (2012). What Drives Quality of Firm Risk Disclosure? The Impact of a National Disclosure Standard and Reporting Incentives under IFRS. The International Journal of Accounting, 47(4), 437-468. https://doi.org/10.1016/j.intacc.2012.10.005

Miihkinen, A. (2013). The usefulness of firm risk disclosures under different firm riskiness, investor-interest, and market conditions: New evidence from Finland. Advances in Accounting, 29(2), 312-331. https://doi.org/10.1016/j.adiac.2013.09.006

Monks, R., \& Minow, N. (2001). Corporate Governance. In The Journal of Finance (Vol. 51). https://doi.org/10.2307/2329384

Morck, R., \& Yeung, B. (2003). Agency Problems in Large Family Business Groups. Entrepreneurship Theory and Practice, 27(4), 367-382. https://doi.org/10.1111/1540-8520.t01-1-00015

Morck, R., Yeung, B., \& Yu, W. (2000). The information content of stock markets: Why do emerging markets have synchronous stock price movements? Journal of Financial Economics, 58(1), 215-260. https://doi.org/10.1016/S0304-405X(00)00071-4

Moscariello, N., Pizzo, M., Govorun, D., \& Kostyuk, A. (2019). Independent minority directors and firm value in a principal-principal agency setting: Evidence from Italy. Journal of Management and Governance, 23(1), 165-194. https://doi.org/10.1007/s10997-018-9421-0

Nakano, M., \& Nguyen, P. (2012). Board Size and Corporate Risk Taking: Further Evidence from Japan. Corporate Governance: An International Review, 20(4), 369-387. https://doi.org/10.1111/j.1467-8683.2012.00924.x

Nenova, T. (2003). The value of corporate voting rights and control: A cross-country analysis. Journal of Financial Economics, 68(3), 325-351. https://doi.org/10.1016/S0304-405X(03)00069-2

Nguyen, P. (2011). Corporate governance and risk-taking: Evidence from Japanese firms. Pacific-Basin Finance Journal, 19(3), 278-297. https://doi.org/10.1016/j.pacfin.2010.12.002

Nur Probohudono, A., Tower, G., \& Rusmin, R. (2013). Risk disclosure during the global financial crisis. Social Responsibility Journal, 9(1), 124-137. https://doi.org/10.1108/17471111311307859

O'Brien, J. P. (2003). The capital structure implications of pursuing a strategy of innovation. Strategic 
Management Journal, 24(5), 415-431. https://doi.org/10.1002/smj.308

OECD (A c. Di). (2004). OECD principles of corporate governance: 2004 (rev. version). OECD.

OECD. (2014). Risk Management and Corporate Governance. OECD. https://doi.org/10.1787/9789264208636-en

Oliveira, J., Lima Rodrigues, L., \& Craig, R. (2011). Risk-related disclosures by non-finance companies: Portuguese practices and disclosure characteristics. Managerial Auditing Journal, 26, 817-839. https://doi.org/10.1108/02686901111171466

Paligorova, T. (2010). Corporate risk taking and ownership structure (Working Paper 2010,3). Bank of Canada Working Paper. https://www.econstor.eu/handle/10419/53851

Pathan, S. (2009). Strong boards, CEO power and bank risk-taking. Journal of Banking \& Finance, 33(7), 1340-1350. https://doi.org/10.1016/j.jbankfin.2009.02.001

Peng, M. W., \& Jiang, Y. (2010). Institutions Behind Family Ownership and Control in Large Firms. Journal of Management Studies, 47(2), 253-273. https://doi.org/10.1111/j.1467-6486.2009.00890.x

Power, M. (2004). The Risk Management of Everything: Rethinking the Politics of Uncertainty. Demos.

Radner, R., \& Shepp, L. (1996). Risk vs. profit potential: A model for corporate strategy. Journal of Economic Dynamics and Control, 20(8), 1373-1393. https://doi.org/10.1016/0165-1889(95)00904-3

Rajgopal, S. (1999). Early Evidence on the Informativeness of the SEC's Market Risk Disclosures: The Case of Commodity Price Risk Exposure of Oil and Gas Producers. The Accounting Review, 74(3), 251-280.

Rossi, F. (2016). Corporate Governance, Risk-Taking, and Firm Performance: Evidence from Italy (SSRN Scholarly Paper ID 2726303). Social Science Research Network. Retrieved from https://papers.ssrn.com/abstract=2726303

Said Mokhtar, E., \& Mellett, H. (2013). Competition, corporate governance, ownership structure and risk reporting. Managerial Auditing Journal, 28(9), 838-865. https://doi.org/10.1108/MAJ-11-2012-0776

Shleifer, A., \& Vishny, R. W. (1997). A Survey of Corporate Governance. The Journal of Finance, 52(2), 737-783. https://doi.org/10.1111/j.1540-6261.1997.tb04820.x

Sila, V., Gonzalez, A., \& Hagendorff, J. (2016). Women on board: Does boardroom gender diversity affect firm risk? Journal of Corporate Finance, 36, 26-53. https://doi.org/10.1016/j.jcorpfin.2015.10.003

Sloan, R. G. (2001). Financial Accounting and Corporate Governance: A Discussion (SSRN Scholarly Paper ID 258518). Social Science Research Network. https://doi.org/10.2139/ssrn.258518

Solomon, J. F., Solomon, A., Norton, S. D., \& Joseph, N. L. (2000). A Conceptual Framework for Corporate Risk Disclosure Emerging from the Agenda for Corporate Governance Reform. The British Accounting Review, 32(4), 447-478. https://doi.org/10.1006/bare.2000.0145

Stiglitz, J. E., \& Weiss, A. (1981). Credit Rationing in Markets with Imperfect Information. The American Economic Review, 71(3), 393-410.

$\mathrm{Su}, \mathrm{W} .$, \& Lee, C.-Y. (2013). Effects of corporate governance on risk taking in Taiwanese family firms during institutional reform. Asia Pacific Journal of Management, 30(3), 809-828. https://doi.org/10.1007/s10490-012-9292-x

Volpin, P. F. (2002). Governance with poor investor protection: Evidence from top executive turnover in Italy. Journal of Financial Economics, 64(1), 61-90. https://doi.org/10.1016/S0304-405X(02)00071-5

Wang, C. J. (2012). Board size and firm risk-taking. Review of Quantitative Finance and Accounting, 38(4), 519-542. https://doi.org/10.1007/s11156-011-0241-4

Woods, M., Kajüter, P., \& Linsley, P. (2007). Risk Management, Internal Control and Corporate Governance: International Perspectives. https://www.wiwi.uni-muenster.de/iur/en/publications/33816

Woods, Margaret. (2009). A contingency theory perspective on the risk management control system within Birmingham City Council. Management Accounting Research, 20(1), 69-81. https://doi.org/10.1016/j.mar.2008.10.003

Wright, P., Ferris, S. P., Sarin, A., \& Awasthi, V. (1996). Impact of Corporate Insider, Blockholder, and Institutional Equity Ownership on Firm Risk Taking. The Academy of Management Journal, 39(2), 441-463. https://doi.org/10.2307/256787 
Yermack, D. (1996). Higher market valuation of companies with a small board of directors. Journal of Financial Economics, 40(2), 185-211. https://doi.org/10.1016/0304-405X(95)00844-5

Zhang, X., Taylor, D., Qu, W., \& Oliver, J. (2013). Corporate risk disclosures: Influence of institutional shareholders and audit committee. Corporate Ownership and Control. https://doi.org/DOI:10.22495/cocv10i4c3art5

Zingales, L. (1994). The Value of the Voting Right: A Study of the Milan Stock Exchange Experience. The Review of Financial Studies, 7(1), 125-148. https://doi.org/10.1093/rfs/7.1.125

\section{Appendix A - Variables definitions}

\begin{tabular}{|c|c|}
\hline \multicolumn{2}{|l|}{ Dependent Variable } \\
\hline Risk Awareness Indicator & Score from 0 to 10 . \\
\hline \multicolumn{2}{|l|}{ Risk Awareness Indicator composition } \\
\hline 1. Risk Committee & Equal to 1 if the company has a Risk Committee, 0 otherwise. \\
\hline 2. Responsible of Internal Control & Equal to 1 if the company has appointed an individual to guarantee the quality of the Internal Control \\
\hline System & System, 0 otherwise. \\
\hline 3. Risk Manager & $\begin{array}{l}\text { Equal to } 1 \text { if the company has a Chief Risk Officer (CRO) or an employee that serves as a risk } \\
\text { manager, } 0 \text { otherwise. }\end{array}$ \\
\hline $\begin{array}{l}\text { 4. Presence of Internal Control } \\
\text { System section }\end{array}$ & $\begin{array}{l}\text { Equal to } 1 \text { if the company has a section on the Internal Control System in its corporate governance } \\
\text { report, } 0 \text { otherwise. }\end{array}$ \\
\hline $\begin{array}{l}\text { 5. Extensively Internal Control } \\
\text { System section }\end{array}$ & $\begin{array}{l}\text { Equal to } 1 \text { if the company has an extensive section on the Internal Control System in the corporate } \\
\text { governance report, } 0 \text { otherwise. }\end{array}$ \\
\hline 6. Centralized Risk Strategy & Equal to 1 if the company has a centralized risk strategy, 0 otherwise. \\
\hline 7. CoSO Framework & Equal to 1 if the company refers to International CoSO Framework, 0 otherwise. \\
\hline 8. Risk Management function & Equal to 1 if the company has a risk management function, 0 otherwise. \\
\hline 9. Risk Appetite Framework & Equal to 1 if the company has a risk appetite framework, 0 otherwise. \\
\hline $\begin{array}{l}\text { 10. Internal Control over Financial } \\
\text { Reporting }\end{array}$ & Equal to 1 if the company has the Internal Control over Financial Reporting, 0 otherwise. \\
\hline \multicolumn{2}{|l|}{ Independent Variables } \\
\hline Ownership & The percentage of shares owned by the major shareholders. \\
\hline InstitutionalInvestor & $\begin{array}{l}\text { Equal to } 1 \text { if the company ownership structure has at least } 20 \text { percent of institutional investors, } 0 \\
\text { otherwise. }\end{array}$ \\
\hline Shareholders' Agreement & Equal to 1 if the company has in place a shareholders agreement, 0 otherwise. \\
\hline \multicolumn{2}{|l|}{ Control variables } \\
\hline Size & The natural logarithm of total assets at the end of the fiscal year. \\
\hline ROA & Ratio of earnings before interest and taxes to total assets. \\
\hline DebtRatio & Ratio of total debts to total assets. \\
\hline Employees & Number of employees. \\
\hline
\end{tabular}

\section{Copyrights}

Copyright for this article is retained by the author(s), with first publication rights granted to the journal.

This is an open-access article distributed under the terms and conditions of the Creative Commons Attribution license (http://creativecommons.org/licenses/by/4.0/). 